\title{
APPROACHES TO ERADICATE ABSOLUTE POVERTY IN GUANGDONG PROVINCE, THE PEOPLE'S REPUBLIC OF CHINA
}

Jinhua Wu

NO. 45

December 2021
ADB EAST ASIA WORKING PAPER SERIES 



\section{ADB East Asia Working Paper Series}

\section{Approaches to Eradicate Absolute Poverty in Guangdong Province, the People's Republic of China}

Jinhua Wu

No. 45 | December 2021
Jinhua Wu is the former director of the International Financial Cooperation Office of Guangdong Provincial Department of Finance, and second-level inspector of Guangdong Provincial Department of Finance.

This paper was prepared as a background paper to "Poverty, Vulnerability, and Fiscal Sustainability in the People's Republic of China” under TA 8997-PRC:

Promoting Partnerships for South-South Cooperation II. 
(C) 2021 Asian Development Bank

6 ADB Avenue, Mandaluyong City, 1550 Metro Manila, Philippines

Tel +632 8632 4444; Fax +63286362444

www.adb.org

Some rights reserved. Published in 2021.

Printed in the Philippines

Publication Stock No. WPS210503-2

DOI: http://dx.doi.org/10.22617/WPS210503-2

The views expressed in this publication are those of the authors and do not necessarily reflect the views and policies of the Asian Development Bank (ADB) or its Board of Governors or the governments they represent.

ADB does not guarantee the accuracy of the data included in this publication and accepts no responsibility for any consequence of their use. The mention of specific companies or products of manufacturers does not imply that they are endorsed or recommended by ADB in preference to others of a similar nature that are not mentioned.

By making any designation of or reference to a particular territory or geographic area, or by using the term "country" in this document, $A D B$ does not intend to make any judgments as to the legal or other status of any territory or area.

This work is available under the Creative Commons Attribution 3.0 IGO license (CC BY 3.0 IGO)

https://creativecommons.org/licenses/by/3.0/igo/. By using the content of this publication, you agree to be bound by the terms of this license. For attribution, translations, adaptations, and permissions, please read the provisions and terms of use at https://www.adb.org/terms-use\#openaccess.

This CC license does not apply to non-ADB copyright materials in this publication. If the material is attributed to another source, please contact the copyright owner or publisher of that source for permission to reproduce it. $\mathrm{ADB}$ cannot be held liable for any claims that arise as a result of your use of the material.

Please contact pubsmarketing@adb.org if you have questions or comments with respect to content, or if you wish to obtain copyright permission for your intended use that does not fall within these terms, or for permission to use the ADB logo.

Corrigenda to ADB publications may be found at http://www.adb.org/publications/corrigenda.

Notes:

In this publication, " $\$$ " refers to United States dollars and "CNY" refers to yuan.

ADB recognizes "China" as the People's Republic of China.

The ADB East Asia Working Paper Series is a forum for stimulating discussion and eliciting feedback on ongoing and recently completed research and policy studies undertaken by the East Asia Department of the Asian Development Bank (ADB) staff, consultants, or resource persons. The series deals with key economic and development problems, as well as conceptual, analytical, or methodological issues relating to project/program economic analysis, and statistical data and measurement. The series aims to enhance the knowledge on Asia's development and policy challenges; strengthen analytical rigor and quality of ADB's country partnership strategies, and its subregional and country operations; and improve the quality and availability of statistical data and development indicators for monitoring development effectiveness.

The ADB East Asia Working Paper Series is a quick-disseminating, informal publication whose titles could subsequently be revised for publication as articles in professional journals or chapters in books. The series is maintained by the East Asia Department. 


\section{CONTENTS}

List of Figures $\quad$ v

Abbreviations $\quad$ vi

Abstract $\quad$ vii

I. Basic Economic and Social Indicators of Guangdong Province 1

A. Population and Economic Development 1

B. Per Capita Income and Expenditure 1

II. Overview of Poverty Reduction in Guangdong Province 4

A. History of Poverty Alleviation and Development 4

B. Results of Poverty Reduction Efforts 6

C. Guangdong's Experience in Poverty Reduction 8

III. Important Measures by Finance Departments in Guangdong Province 9 to Lift the Poor People out of Poverty

A. Guarantee Financial Inputs and Make Poverty Alleviation a Priority in 9 Financial Guarantees

B. Ensure the Results of "Two Assurances, Three Guarantees, 10 and One Equivalence" Policy

C. Reform and Innovate the Use of Agriculture-Related Funds $\quad 10$

D. Leverage Tax Policies and Social Resources 11

E. Regulate the Management and Use of Funds and Strengthen 11 the Supervision of Poverty Alleviation Funds

F. Strengthen International Cooperation in Poverty Alleviation 12

IV. Guangdong's Experiences in the "Blood-Forming Type" of Poverty Alleviation 14

A. Provide Sufficient Funding Support to Agriculture Sector 14

B. Enhance the Efficiency of Funds used for Employment-Driven Poverty Alleviation 14

C. Optimize the Leading Role of Government Procurement in Promoting 15 "E-commerce + Consumption for Poverty Alleviation"

D. Create New Ways to Use Poverty Alleviation Funds, and Explore Investment 15 in Assets for Poverty Alleviation

E. Support Targeted Poverty Alleviation Through the Tourism Industry 16

F. Implement Collaboration Between the Eastern and Western Regions 16 
iv $\quad$ ADB East Asia Working Paper Series No. 45

$\begin{array}{lll}\text { V. Challenges and Pathways to Poverty Reduction } & 17\end{array}$

Appendix 1: Case Study on Poverty Reduction in Nanxiong City in Shaoguan 18

Appendix 2: Case Study on Poverty Reduction in Lianzhang Village, Yingde, Qingyuan 21

$\begin{array}{lr}\text { References } & 27\end{array}$ 


\section{LIST OF FIGURES}

\section{Figures}

$1 \quad$ Per Capita Disposable Income of Guangdong Residents, 2013-2019 1

2 Guangdong Per Capita Consumption Expenditure, 2013-2019 2

3 Engel Coefficient for Guangdong Residents, 2013-2019 (\%) 3 


\section{ABBREVIATIONS}

$\begin{array}{lll}\text { ADB } & - & \text { Asian Development Bank } \\ \text { COVID-19 } & - & \text { coronavirus disease } 2019 \\ \text { CPC } & - & \text { Communist Party of China } \\ \text { CNY } & - & \text { Chinese yuan } \\ \text { PRC } & - & \text { People's Republic of China }\end{array}$




\begin{abstract}
This paper provides the overview of the measures taken in Guangdong Province, the People's Republic of China to lift the province's 1.7 million poor people and 2,277 poor villages out of absolute poverty by the end of 2020. The fiscally supported measures focused on the development of mountain areas and providing financial and business resources to the targeted poor population. Although the fiscal measures achieved the eradication of the absolute poverty, key remaining challenges are also identified in the paper. The main challenge is how the rural low income households remain out of poverty without the public support going forward. The rural low income area needs to be further developed to be able to provide stable labor income opportunities to the remaining vulnerable population. The paper proposes the direction for the next steps.
\end{abstract}





\section{BASIC ECONOMIC AND SOCIAL INDICATORS OF GUANGDONG PROVINCE}

\section{A. Population and Economic Development}

Guangdong is a province in the People's Republic of China (PRC) with a large population. At the end of 2019, there were 115.2 million permanent residents, of whom $52.3 \%$ were men and $47.7 \%$ were women. ${ }^{1}$ Almost three-fourths (74.7\%) of the population were aged 15-64, while those $0-14$ years old made up $16.3 \%$, and those above 65 years old comprised $9.0 \%$ of the population. The population comprised $71.4 \%$ urban, and $28.6 \%$ rural in the same period.

Guangdong is the largest province by gross domestic product in the PRC. In 2019, its gross domestic product was CNY10.8 trillion, with the primary sector accounting for $4.0 \%$, the secondary sector $40.5 \%$, and the tertiary sector $55.5 \%$.

\section{B. Per Capita Income and Expenditure}

The per capita disposable income of the province from 2013 to 2019 rose from CNY23,420.8 in 2013 to CNY39,014 in 2019, an increase of $66.6 \%$ over 6 years and an average annual growth rate of $8.9 \%$ (Figure 1). The increase in per capita disposable income of urban residents over the same period was $62.9 \%$, and $70.0 \%$ for rural residents-much higher than that of urban residents, which was of great significance in narrowing the urban-rural gap. In 2019, the income ratio of urban and rural residents in Guangdong was 2.6, down from 2.7 in 2013.

Figure 1: Per Capita Disposable Income of Guangdong Residents, 2013-2019

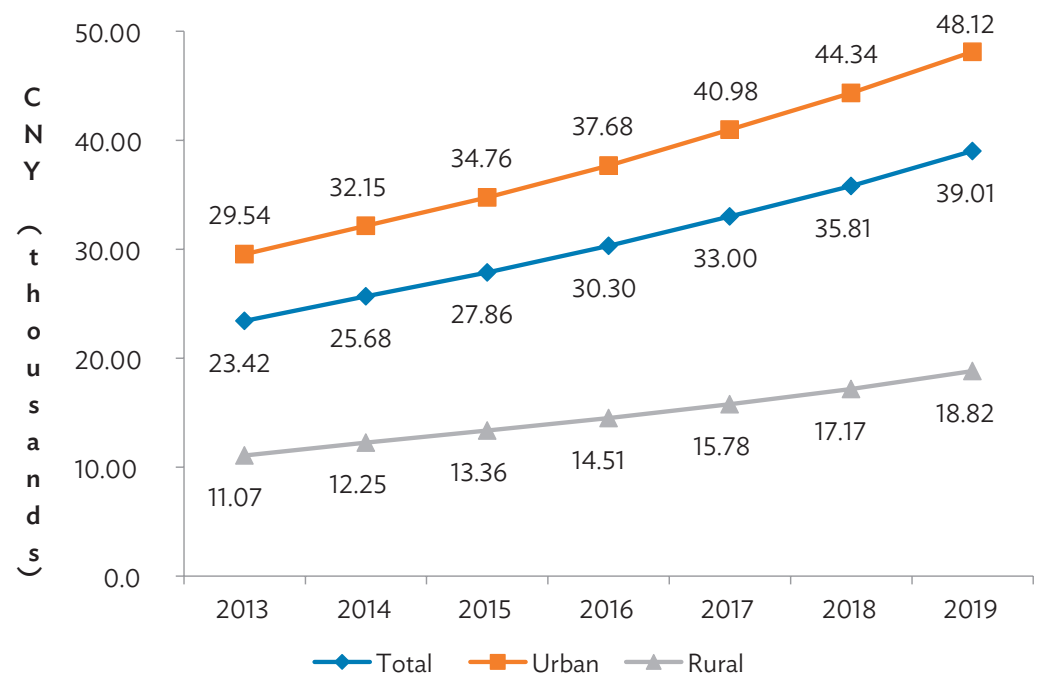

CNY = yuan.

Source: Guangdong Provincial Bureau of Statistics. 2020. Guangdong Statistical Yearbook 2020. Guangdong: China Statistics Press.

1 All data in this paper are derived from the Guangdong Provincial Department of Finance and Guangdong Provincial Poverty Alleviation and Development Office unless otherwise indicated. 
The provincial per capita consumption expenditure of Guangdong residents gradually increased from 2013 to 2019, generally rising from CNY17,421 in 2013 to CNY28,994.7 in 2019, an increase of 66.4\% over 6 years, with an average annual growth rate of $8.9 \%$ - the same rate as Guangdong's per capita disposable income. The per capita consumption expenditure of urban residents increased by $59.2 \%$, while rural residents posted a higher rate of $89.6 \%$, which helped boost the growth of domestic demand (Figure 2).

Figure 2: Guangdong Per Capita Consumption Expenditure, 2013-2019

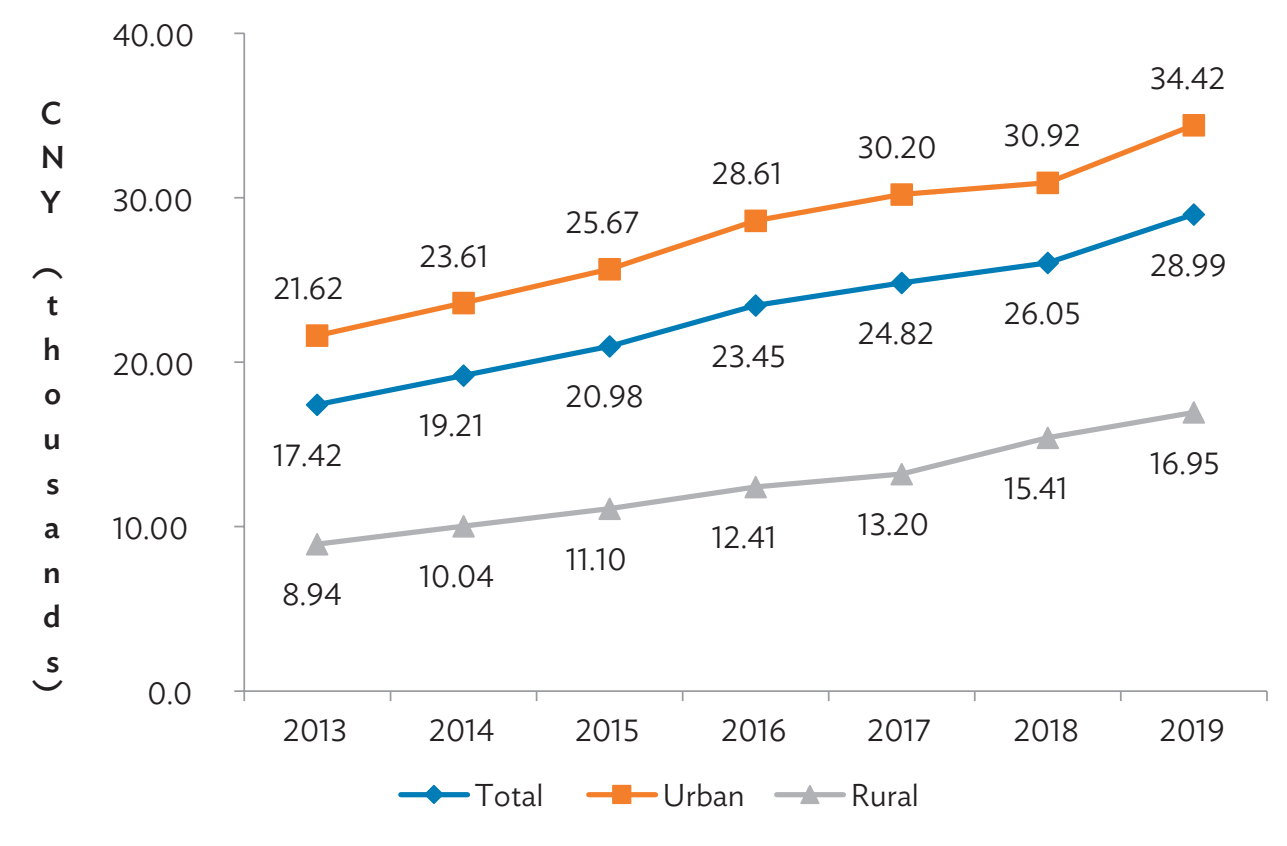

CNY = yuan.

Source: Guangdong Provincial Bureau of Statistics. 2020. Guangdong Statistical Yearbook 2020. Guangdong: China Statistics Press.

The Engel coefficient is the proportion of personal food expenditure to consumption expenditure and serves as an important indicator of poverty level. ${ }^{2}$ In 2013-2019, the Engel coefficient for Guangdong residents decreased gradually, from 35\% in 2013 to 32.3\% in 2019 (Figure 3). The Engel coefficient for urban residents fell by $7.1 \%$, and by $11.9 \%$ for rural residents. In 2019, the Engel coefficient for urban residents was $31.2 \%$, while the Engel coefficient for rural residents was $37.1 \%$. Evidently, the urban-rural gap still remained.

2 Engel theory indicates that the poorer a family, the greater the proportion of the total family expenditures used for food. The proportion of the total expenditures used for food, other things being equal, is the best measure of the material standard of living of a population. 
Figure 3: Engel Coefficient for Guangdong Residents, 2013-2019 (\%)

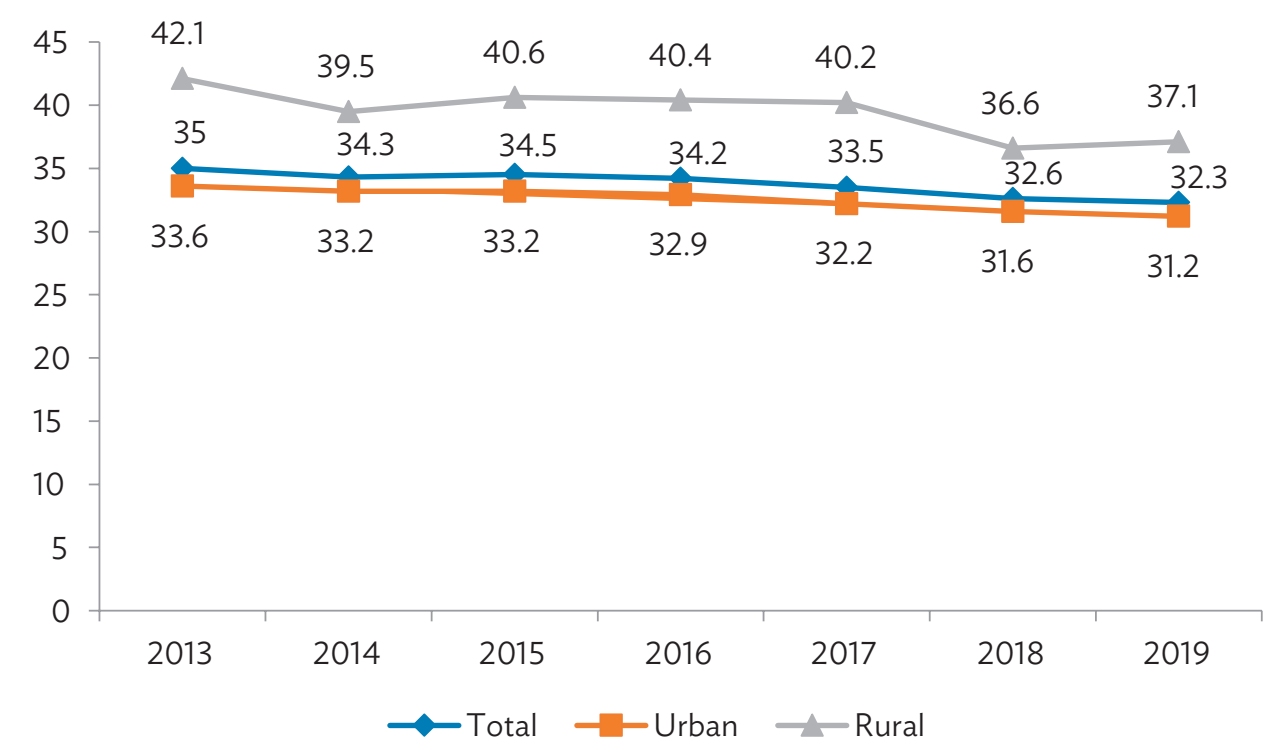

Source: Guangdong Provincial Bureau of Statistics. 2020. Guangdong Statistical Yearbook 2020. Guangdong: China Statistics Press. 


\section{OVERVIEW OF POVERTY REDUCTION IN GUANGDONG PROVINCE}

\section{A. History of Poverty Alleviation and Development}

Guangdong Province has witnessed tremendous economic growth and social development and has scored remarkable achievements since the start of the PRC's reform and opening-up over 4 decades ago-in the 1970s. The Communist Party of China (CPC) Guangdong Provincial Committee and the People's Government of Guangdong Province - the pioneers of the PRC's reform and opening-up-have attached great importance to poverty alleviation, and have always considered poverty alleviation through development as one of the most significant tasks, and provided support at all levels, including funding skills trainings. Guangdong kept on innovating and improving its systems and institutions for poverty alleviation and development. It successively implemented strategic measures such as the development of mountain areas, and the 10-year outline for development-oriented poverty alleviation, guided by the policy thrust of "Plan the Poverty Alleviation to Households, Allocate Responsibilities to Specific Persons."

\section{Development of Mountain Areas (1984-1990)}

In 1984, the CPC Central Committee and the State Council jointly issued the "Notice on Helping Impoverished Areas Alleviate Poverty as Soon as Possible." Poverty was a significant problem in the mountain areas of Guangdong Province at that time. In 1986, four counties in Guangdong Province, namely, Dapu, Fengshun, Wuhua, and Longchuan, were listed among the first batch of poor counties with state support. The CPC Guangdong Provincial Committee and the People's Government of Guangdong Province put forward the policy of "Developing Mountain Areas and Achieving Prosperity by Mountain Agriculture" in 1984, calling for developing mountain areas so that they can shake off poverty and become better off through mountain management. This meant reducing the number of poor people with an annual income of less than CNY200 and without adequate food and clothing from 3.9 million in 1985 to 0.2 million by the end of 1990 .

\section{Poverty Reduction Program (1991-2000)}

Guangdong started to fully solve the problem of inadequate food and clothing beginning 1991, when the CPC Guangdong Provincial Committee and the People's Government of Guangdong Province proposed to speed up the pace of overcoming poverty and achieving prosperity in mountain areas. For the first time, poverty alleviation and development plans were undertaken in a comprehensive and systematic manner, as embodied in the Eighth Five-Year Plan, 1991-1995. In 1994, according to the Seven-Year Priority Poverty Alleviation Program (1994-2000), 1.2 million people with a net per capita income of less than CNY500 (in constant 1990 prices) were designated as poor. The Program planned for all the poor to have enough food and clothing by 1997. The CPC Guangdong Provincial Committee and the provincial government gave priority to 250,000 people with a net income per capita of less than CNY1,200 from 16 poor counties. By January 1998, the provincial government announced that absolute poverty had been basically eradicated in Guangdong Province, and the goal of raising the level of adequate food and clothing by 2000 had been achieved.

\section{Implementation of the "Outline of Poverty Alleviation and Development in Rural Areas in China (2001-2010)"}

Guangdong formulated the "Outline of Poverty Alleviation and Development in Rural Areas in Guangdong Province" during the Tenth Five-Year Plan Period, 2001-2005; and the "Plan of Poverty Alleviation and Development in Rural Areas in Guangdong Province" during the Eleventh Five-Year Plan Period, 2006-2010 in accordance with the "Outline of Poverty Alleviation and Development in Rural 
Areas in China (2001-2010)," in a bid to promote poverty alleviation work and shift to overall poverty reduction. These aimed to ensure that the impoverished rural population would have adequate food and clothing; that their incomes would grow; and that they would have access to compulsory education, basic medical services, and housing. By the end of 2010, Guangdong had decreased its number of poor people with an annual income of less than CNY1,500 by 7 million.

\section{Implementation of the "Plan the Poverty Alleviation to Households, Allocate Responsibilities to Specific Persons” (2010-2015)}

In June 2009, the CPC Guangdong Provincial Committee and the provincial government issued the "Opinion on the implementation of Plan the Poverty Alleviation to Households, Allocate Responsibilities to Specific Persons." By the end of 2015, two rounds of "Plan the Poverty Alleviation to Households, Allocate Responsibilities to Specific Persons" (hereinafter referred to as "Double To") had been launched. "Double to" had the following objectives: (i) By 2015, the per capita income of people living below the poverty line should reach or exceed $45 \%$ of the overall rural per capita income of the province that year, constantly lifting people out of poverty; (ii) the rural per capita income in poverty-stricken villages should exceed $60 \%$ of the overall rural per capita income of the province that year, and the rural collective economic income of villages should reach or exceed CNY50,000; (iii) the total relocated population in poverty-stricken villages with limited production and living conditions (3,000 villages and 60,000 households included) should reach 300,000; and (iv) 541,500 dilapidated rural houses should be renovated.

Key assistance was provided to poverty-stricken villages and poor people in Enping, as well as 14 prefecture-level cities in the eastern, western, and northern regions of Guangdong Province.

As of the end of 2012, the first round of efforts yielded an average collective income in the assisted poverty-stricken villages of CNY110,000. The per capita net income of the poor people assisted reached CNY7,762. The second round was implemented toward the end of 2015, and resulted to income from the collective economy per village

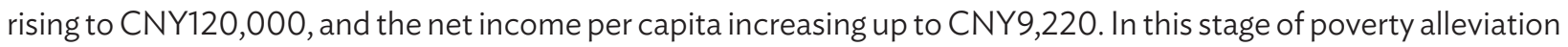
work, the relocation of 281,100 poor people (involving 3,000 villages, and 57,000 households) were completed. This translated to $93.7 \%$ of the relocation target of poor people $(300,000)$. Also, 568,000 dilapidated houses in rural areas were renovated, exceeding the originally planned number of 541,500. The targets of the two rounds of "Double To" had been basically achieved by the end of 2015.

\section{Targeted Poverty Alleviation (2016-2020)}

In 2016, the CPC Guangdong Provincial Committee and the provincial government implemented actions to alleviate and eliminate poverty, targeting specific populations with the following conditions, as defined by the CPC Central Committee:

(i) disposable income per capita of rural residents should be less than CNY4,000 (in constant 2014 prices) - the "relatively poor people",

(ii) disposable income per capita of a rural village should be less than CNY8,000 (in constant 2014 prices) - the "relatively poor village", and

(iii) the number of poor people account for $5 \%$ of the registered population in the whole village.

Based on these standards, 2,277 relatively poor villages were identified in Guangdong Province, with 0.7 million households and 1.8 million people identified as being in relative poverty (after dynamic adjustments in 2017, 0.6 million households and 1.6 million people were in relative poverty). 
It was emphasized that the overall objective was to accomplish the poverty alleviation tasks on schedule by 2020, and that the basic requirements for poverty alleviations were "two assurances, three guarantees, and one equivalence", i.e., assuring the rural poor population that they had enough to eat and to wear; guaranteeing them access to compulsory education, basic medical services, and safe housing; and ensuring that the major indications of basic public services were equivalent to Guangdong's average level. The poverty alleviation plan focused on the implementation of eight poverty alleviation projects, namely, developing local industries, boosting employment, securing basic needs through social security, education and culture, providing medical insurance and aid, renovation of dilapidated housing, infrastructure construction, and improving the living environment.

\section{B. Results of Poverty Reduction Efforts}

Since 2016, Guangdong has taken the lead in exploring ways for poverty alleviation. Apart from the "relatively poor people" and the "relatively poor villages", priority was given, under the same conditions of the CPC Central Committee, to (i) one administrative village whose relatively poor population accounts for more than $5 \%$ of its total registered population; (ii) one administrative village with farmers living in dilapidated mud-brick houses (thatched houses), accounting for over $10 \%$ of its total registered population; and (iii) one village that is an old revolutionary base area or ethnic minority area, located in a limestone area, or an area for resettlement due to construction of a provincial dam.

Based on the poverty alleviation standards until 2020, there were 1.6 million people living in relative poverty in Guangdong Province and 2,277 villages living in relative poverty that have met the standards for poverty exit, thereby achieving the overall objectives of poverty alleviation. The goals that were set in the implementation of targeted poverty alleviation were accomplished on schedule by the end of 2020. Arrangements for collaboration on poverty alleviation between the eastern and western regions have been implemented, facilitating nationwide poverty alleviation, as shown in the following.

\section{Number of Poor People}

After two rounds of "Double To", by the end of 2015, Guangdong had reached the objective of solving the problem of absolute poverty per national standards according to the national poverty line. The number of poor people had continued to decline, with the population living in absolute poverty the first to exit poverty.

From 2009 to 2016, the number of impoverished villages in Guangdong Province had declined by 5,978 and the number of poor people decreased by 2,476,000. From 2016 to 2020, the population in relative poverty in the province had fallen to 1,615,000, and 2,277 villages on the list of villages in relative poverty were removed from the list. Meanwhile, Guangdong has also provided assistance to Tibet Autonomous Region, Xinjiang Uygur Autonomous Region, Sichuan, and poor counties in a dozen provinces and regions in the central and western regions, helping sister provinces and regions reduce their poor population by more than 5.8 million, and offering stable jobs in Guangdong for 3.9 million poor people from the central and western regions of the country.

\section{Income of the Poor and Social Security}

The income of the poor has been growing, and social security has been steadily improved. In 2019, the disposable income per capita in poverty-stricken villages in Guangdong Province rose to CNY14,331, of which property income grew the most. The property management capacity of the poor was also improved. In terms of expenses, both operating expenses and transfer expenses have grown dramatically. In 2017, the operating expenses together with the transfer expenses accounted for $28.3 \%$ of total income, 
showing an increase of $20 \%$ compared to 2016 , reflecting that the household consumption structure has improved to some extent and that the development goal of the poor population has shifted away from meeting basic life needs to raising household income and living standards.

As of end May 2020, 408,600 poor people who were able and willing to work in Guangdong have been employed; 1,041 "poverty alleviation plants" and "poverty alleviation workshops" have been established; and 17,693 public service jobs have been created. A total of 284,700 skills trainings have been provided and 1,196,000 poor people meeting the conditions for old-age insurance for urban and rural residents have been covered; thus, all those qualified have received support.

By the end of 2019, Guangdong had developed a tightly woven and sturdy safety net, and achieved a comprehensive implementation rate of $98.5 \%$ in policies related to education, basic medical services, serious illness insurance, and old-age insurance. Financial aid for compulsory education to higher education had been provided to needy students from households registered as living in poverty. In 2019, a total of 295,000 such students received financial aid.

The amount of funding provided by finance departments at all levels and the number of aid recipients have increased year on year. A safety net consisting of "three guarantees" (guaranteeing basic medical services + serious illness insurance + medical assistance) has been set up. All eligible poor people were covered by medical insurance, with the proportion of basic medical assistance exceeding $80 \%$. The standards for the renovation of dilapidated houses were raised to CNY40,000 per household, and 344,000 dilapidated houses had been renovated in the province since 2015. Issues regarding safe housing for impoverished households had been resolved completely. Basic livelihood guarantees had been strengthened, and efforts had been made to steadily raise the standards for subsistence allowances for poor residents in urban and rural areas, relief and assistance to support those in extreme poverty, and basic living allowances for orphans.

Needy people affected by the coronavirus disease 2019 (COVID-19) pandemic have been covered by policy guarantees such as temporary assistance, in a timely manner. As of July 2020, Guangdong has granted CNY11,771 million to help people in financial difficulties. In the first half of 2020, a total of about CNY1.7 billion has been provided to needy people as a temporary price subsidy, benefiting more than 13 million people.

\section{Infrastructure, Ecological Environment, and Basic Public Services}

The infrastructure and ecological environment in impoverished areas have markedly improved. The quality of basic public services has been elevated as Guangdong continues to increase investments to improve public services. The task of road concreting in areas (natural villages) designated by the province as relatively poor, with more than 200 people, has basically been completed; the centralized water supply rate of natural villages with more than 20 households in the relatively poor villages has reached $100 \% ; 50.2 \%$ of the villages in relative poverty have rural e-commerce service stations in place, and almost all villages have access to fiber optic networks. The campaign called "cleaning three types of places, dismantling three types of buildings, and controlling three kinds of pollution" has been launched, which is a holistic endeavor. The completion rate for the comprehensive improvement of the living environment of poor villages has reached $100 \%$, and the rates of separation for rainwater and sewage, and sewage treatment facilities coverage in natural villages with more than 20 households have reached about $78.5 \%$ and $67.2 \%$, respectively.

The 2,277 villages designated as poor by the province have transformed into demonstration villages for the new socialist countryside, equipped with 6,678 standardized public toilets and 379,000 upgraded toilets. 
The network coverage rates increased for public service stations (99.8\%), standardized health stations (98.5\%), and express logistics (80.2\%) in impoverished villages. All 2,277 low-income villages have access to optical fibers with speed above 100 megabits per second, with a network coverage rate of $100 \%$.

Public sports facilities have been improved. In 1,136 towns, public fitness squares have been built; and 19,150 of 19,795 administrative villages have sports and fitness venues in place. In 2018, the focus was on the construction of one set each of 10-station fitness trail equipment in 2,277 povertystricken villages in Guangdong, and proactive support for the construction of public sports facilities in underdeveloped areas.

\section{Guangdong's Experience in Poverty Reduction}

Looking back at its poverty reduction experience over the past 40 years, Guangdong has made remarkable achievements.

The provincial party committee and the provincial government have placed poverty reduction in an important position, upheld the "people-centered" development concept, and placed poverty reduction within the whole economic and social context so as to make holistic plans. The province combined “blood transfusion” “输血”) and “blood-making” “造血”), ${ }^{3}$ promoted development-oriented poverty alleviation, and guaranteed a holistic approach where developing local industries, employment, and consumption were the starting points. Great importance was attached to education and medical services, and housing was accorded for poor people, in order to build a comprehensive and high-level social security system. Combining "special poverty alleviation programs, poverty alleviation by developing local industries, and social assistance in poverty alleviation" made targeted poverty alleviation possible, featuring government leadership, market participation, and social coordination.

At the same time, the government's poverty alleviation efforts motivated people by building their confidence and capacity to pull themselves out of poverty. Poor villages were used as demonstration sites for the new countryside, showcasing poverty alleviation and revitalization of the countryside.

3 Guangdong provides not only financial assistance but also training and intellectual support, to transform assistance from blood transfusion type to blood-forming type-measures for self-development and motivation of poor people to get out of poverty. 


\section{IMPORTANT MEASURES BY \\ FINANCE DEPARTMENTS IN GUANGDONG PROVINCE TO LIFT THE POOR PEOPLE OUT OF POVERTY}

Finance departments in Guangdong have always regarded poverty alleviation as an important political task. The finance departments laid out its main objective and standards for poverty alleviation as: The relatively poor people are provided with sufficient food, clothing, opportunities for compulsory education, basic medical care, and housing resources. Guided by the overall objectives and then current standards, they tackled outstanding problems using the "two assurances, three guarantees, and one equivalence" approach to pursue the steady eradication of poverty and prevent slipping back into poverty. They have sustained financial support for poverty alleviation work, strived to overcome the impact of the COVID-19 pandemic, and provided a strong financial guarantee to ensure success in the battle against poverty. From 2016 to 2020, the financial support for poverty alleviation made by the province reached CNY73.2 billion, a record high.

\section{A. Guarantee Financial Inputs and Make Poverty Alleviation a Priority in Financial Guarantees}

Guangdong has continuously strengthened its financial functions and financial coordination through the following targeted measures:

(i) Increase general transfer payments. In 2020, key transfer payments, such as balanced transfer payments from the provincial level to cities and counties, financial compensation for ecological protection zones, basic financial guarantees at the county level, and subsidies for regions inhabited by ethnic minorities and disadvantaged former revolutionary base areas reached CNY177.8 billion, covering 86 counties (cities, districts) in the eastern, western, and northern regions of Guangdong; and the financially weak areas in the Pearl River Delta.

(ii) Strengthen the guarantees for financial support from special poverty alleviation funds. From 2016 to 2018, CNY25.5 billion was invested in poverty alleviation, the development of local industries and employment creation, and the creation of employment assistance to help households registered as living in poverty. Per policy, CNY5.9 billion was provided as subsistence allowances to those registered as living in poverty and unable to work.

(iii) Deepen the reforms in overall planning and integration of agriculture-related funds at the provincial level. In 2020, the amount of agriculture-related funds at the provincial level consolidated by cities and counties reached CNY25.6 billion. All localities could use the funds for poverty alleviation and revitalizing key areas in the countryside, such as for improving the living environment in rural areas, as long as they ensured that the assessment of cities and counties in agriculture-related areas, conducted at the provincial level, was completed.

(iv) Implement arrangements for collaboration on poverty alleviation between the eastern and western regions. Guangdong increased horizontal transfer payments, and established a guarantee mechanism for yearly increases in input. Since 2016, it has allocated CNY17.1 billion to aid western counties, with the aid increasing from CNY10.4 million in 2016 to CNY62 million in 2020. From 2018 to 2019, the province invested 37.9 billion in surplus quotas generated by linking the amount of land used for construction and adjusted interprovincially, thus raising social aid funds of CNY11 billion. 


\section{B. Ensure the Results of "Two Assurances, Three Guarantees, and One Equivalence" Policy}

Targeted policies have been implemented to step up efforts in poverty alleviation through increasing access to education, boosting employment, improving medical services, issuing subsistence allowances, and undertaking infrastructure construction in poor villages to promote equalized public services.

(i) Comprehensive implementation of policies on targeted poverty alleviation through education. In 2020, finance departments at the provincial level allocated CNY776 million in incremental funds for student aid under the program on targeted poverty alleviation through education. About 300,000 students were assisted to ensure that they will not drop out of school due to financial difficulties.

(ii) Proactive implementation of policies to support employment and entrepreneurship. In 2020, CNY1.9 billion special funds were allocated by the provincial government to promote employment and startups, proactively supporting employment and entrepreneurship policies such as support for Cantonese Cuisine Chefs Program, Nanyue Housekeeping Program, e-commerce in rural areas, discounts, bonuses, and subsidies for guaranteed loans to startups, Dream Initiative, ${ }^{4}$ employment and entrepreneurship policies, and service subsidies.

(iii) Expansion of coverage of funds to improve medical services. In 2020, the finance departments allocated CNY3.3 billion for urban and rural medical assistance funds especially to support economically underdeveloped areas. The funds aimed to guarantee that the basic medical assistance for recipients of subsistence allowances exceeded $80 \%$ of medical expenses.

(iv) Strengthened targeted poverty alleviation by providing allowances to assist poor people in meeting their basic needs. In 2020, CNY9.1 billion in assistance funds were allocated by the finance department at the provincial level to support the province, especially economically underdeveloped areas. The minimum subsistence allowance for urban recipients was increased from CNY554 to CNY609 per month; and for rural recipients, from CNY251 per month to CNY276 per month.

(v) Promotion of infrastructure construction in poor villages. In 2020, the provincial finance department allocated CNY1.2 billion to continue to support the province's facility for the safe treatment of domestic wastes, classification of domestic wastes, operation and maintenance of town-level sewage treatment facilities, and rural domestic sewage treatment process demonstration bases. The subsidies to help localities promote and accelerate the construction, management, protection, and operation of rural roads were increased by CNY3 billion.

\section{Reform and Innovate the Use of Agriculture-Related Funds}

Since 2018, Guangdong Province has implemented reforms in agriculture-related funds, focusing on six key points to provide a solid financial foundation for poverty alleviation.

(i) Focus on key projects. The limited agriculture-related funds have been allocated to major livelihood projects to solve key issues, such as renovation projects on mud brick houses and river training programs in poverty-stricken areas.

$4 \quad$ The Dream Initiative is an industrial workers training plan held by the Guangdong provincial government. 
(ii) Drive rural revitalization. Local ecology, industry, tourism, culture, and other resources have been integrated to create new sources of growth in rural areas by leveraging preferential policies, allocating funds, and integrating resources. The projects in rural revitalization programs are complementary to each other and are built on contiguous land. For example, Yingde City has allocated CNY220 million to build a demonstration area in Xiniu Town, which has increased the income for both village residents and the rural collective economic organizations.

(iii) Maintain containment efforts during production activities. Meizhou municipality has arranged CNY37.1 million as the interest subsidy to ensure the stable production and supply of swine.

(iv) Plan the program in advance. Firmly establish the awareness of "planning first, investing second;" take the initiative to increase the investment in the early stage of the project; and strengthen the management of the project library.

(v) Integrate financial resources. The agriculture-related funds from provinces, cities, and counties have been integrated to form a new consolidated force for poverty alleviation in agriculture. For example, Xinxing County has integrated a total of CNY470 million allocated from provincial, municipal, and county levels for the improvement of rural settlements and the construction of the rural roads to align with "Four Good" standards.

(vi) Simplify the approval process. All local governments have been actively exploring innovative approval models and streamlined the approval process to build the agriculture-related poverty alleviation projects at fast speed, good quality, and low cost.

\section{Leverage Tax Policies and Social Resources}

Guangdong has supported the entrepreneurship and employment of key groups through conducive tax policies. Preferential tax and fee policies have been extended in support of and to guide poverty alleviation. The province has implemented the national policies exempting donations of poverty alleviation goods from value-added tax, and donations for poverty alleviation from pretax deduction of income tax. Also, the province has exempted government funds related to poverty alleviation and relocation projects from administrative fees. Departments of finance, taxation, and poverty alleviation have established a coordination mechanism to share information on "target poverty alleviation areas" and the situation of goods donations across the province. Aside from promoting the implementation of tax policies related to poverty alleviation, Guangdong has also provided personalized policy guidance and has answered taxpayers' questions about tax policies.

\section{E. Regulate the Management and Use of Funds and Strengthen the Supervision of Poverty Alleviation Funds}

Supervision of the use of poverty alleviation funds takes a holistic approach, where supervision and inspection efforts have been increased, dynamic monitoring mechanism actively promoted, management of poverty alleviation assets strengthened, and transparency of fund use enhanced.

(i) Strengthen inspection, supervision, and audit of poverty alleviation funds. Key inspections on the use of poverty alleviation funds have been organized and "dual monitoring" is conducted for both the performance of and progress in use of funds, to ensure that funds are used precisely and effectively.

(ii) Improve the dynamic monitoring system of poverty alleviation funds. The provincial government has leveraged modern information technologies such as cloud computing 
and big data to establish a simple, practical, real-time, and synchronized dynamic monitoring system to achieve comprehensive, true, and accurate dynamic supervision of poverty alleviation funds and projects. By the end of December 2019, 42 central and 48 provincial funds totaling CNY131 billion have been included in the dynamic monitoring system.

(iii) Prepare documents on asset management for poverty alleviation. Guangdong is accelerating the establishment of an asset management system with verified asset background, clear ownership, scientific classification, clear main responsibilities, reasonable income distribution, and standardized operation and management. While it has implemented a standardized asset management system, more is being done to improve the mechanism for long-term and stable operations to achieve greater progress and lay a solid foundation to bring alleviation efforts and revitalization programs together. This will also avoid the waste or loss of assets.

\section{F. Strengthen International Cooperation in Poverty Alleviation}

Guangdong is promoting international best practices and Guangdong's experience on poverty alleviation by tapping into both domestic and international resources. The provincial government has forged closer cooperation with the Asian Development Bank (ADB), World Bank, and other international financial institutions on undertakings in poverty alleviation through the following:

(i) Strengthen international cooperation in poverty alleviation and maximize best international practices. The Chaonan Water Resource Protection and Utilization Exemplary Project, ${ }^{5}$ involving an investment of CNY1.4 billion and a $\$ 100$ million loan from ADB improved the sanitation standards for over 1.2 million local residents at Chaonan District, ensuring sufficient water supply and enhancing the living quality of residents in the district. This project promotes an integrated approach of structural and nonstructural measures to water resources management, integrating urban-rural water supply systems and reducing water losses, watershed management through reforestation, pollution prevention and water quality monitoring, public awareness building, and institutional capacity development. These comprise the best practices and innovations in water resources management that contribute to poverty reduction and are being replicated in water projects in South Asia and Southeast Asia. The agricultural nonpoint source pollution control project funded by the World Bank emphasized more on farmers' self-sufficiency skills. As a result, over 281 green agriculture management personnel and 1,300 technical specialists including 1,200 at the township or village level, have received proper training on green agriculture. In turn, this provided a total of 263,000 training opportunities to agronomists, farmers, and entrepreneurs from municipal, county, township, and village levels and 7,000 training opportunities to poverty-stricken farmers.

The World Bank also provided funding support for Guangdong's compulsory education program, benefiting over 517,280 teachers and students in 16 poverty-stricken cities and counties, as well as 1,145 families living in absolute poverty. A total of 30,000 headmasters and teachers have been undergoing training programs funded by the World Bank, and it is estimated that over 1.2 million students from poverty-stricken regions would have benefited from this education empowerment scheme.

5 Asian Development Bank. 2021a. https://www.adb.org/projects/46079-002/main. 
(ii) Leverage international financial institutions as an external communication platform. Guangdong promotes its poverty alleviation experiences to the outside world. For example, ADB's multitranche Guangdong Energy Efficiency and Environment Improvement Investment Program ${ }^{6}$ increased energy efficiency, created jobs, and helped reduce poverty, thereby contributing to the economic development of Guangdong Province. The Guangdong Efficiency Power Plant is recognized as a model in energy efficiency investments. This model was replicated in Shandong and Hebei provinces, and is ready for further replication in other countries in the region.

After the success of the East Asia Livestock Waste Management Project funded by the Guangdong Global Environment Facility, the World Bank launched several similar projects in Thailand and Viet Nam to promote Guangdong's best practices on marsh gas utilization, where experts from Guangdong were invited to supervise these projects.

After the success of a migrant worker training scheme funded by the World Bank, Guangzhou Industry \& Trade Technician College, a recipient of this scheme, signed a cooperation agreement with the Education Ministry of Bangladesh on technician training, thus promoting the "going global" objective of the PRC's technician education. This was the first of this kind with the direct participation of an international financial institution. The "going global" component of Guangdong's vocational education and development has become a "Belt and Road" mode for other countries.

6 Asian Development Bank. 2021b. https://www.adb.org/projects/39653-023/main. 


\section{GUANGDONG'S EXPERIENCES IN THE “BLOOD-FORMING TYPE” OF POVERTY ALLEVIATION}

Guangdong's poverty alleviation scheme focuses more on self-sufficiency of the poverty-stricken population, supported by motivational training and education assistance. In other words, from a "blood transfusion type", Guangdong has transformed to the "blood-forming type" of poverty alleviation. Below are some of Guangdong's significant experiences.

\section{A. Provide Sufficient Funding Support to Agriculture Sector}

Guangdong has utilized all types of agricultural development funds for poverty alleviation. Between 2018 and 2020, over CNY7.5 billion was spent on provincial-level modern agro-industrial parks. Guangdong also rolled out many policies with over CNY1 billion for spending each year between 2019 and 2021 on agricultural enhancement projects, special breeding industry, agricultural facility, agricultural products/ primary processing industry, and leisure agriculture, so that each lagging village will have its leading farming industry.

In addition, agricultural branding has been financially supported and agricultural product traceability platforms were established to ensure product quality. All cities and counties in Guangdong are encouraged to highlight their initiatives and innovative pursuits. For example, Foshan city set up special support funds wherein eligible enterprises in the fields of exhibition stores, production-marketing matchmaking, and online sales, are incentivized and subsidized for as high as CNY500,000.

Zhuhai city allocates CNY30 million each year to encourage enterprises to utilize the city's market resources, capital, and talents, to propel industry-driven poverty alleviation. Enterprises or individuals are motivated to launch their start-ups in poverty-stricken villages and promote resource integration in these villages.

\section{B. Enhance the Efficiency of Funds used for Employment-Driven Poverty Alleviation}

Guangdong has established an effective employment-driven poverty alleviation policy. A provincial-level, employment-driven poverty alleviation recognition measure was established. ${ }^{7}$ Enterprises were provided with increased subsidies to provide employment opportunities to the unemployed coming from the low income group. Fiscal funding was used to create jobs for the poor, such as for village sanitation, road maintenance, and elderly care, among others.

In addition, Guangdong set up various special funds to support poverty alleviation projects, production plants, and workshops. Funds management was standardized, and matching events between poverty-stricken residents and enterprises were carried out. Guangdong also introduced a series of subsidy collection methods for poverty-stricken residents who received skillset enhancement programs. Targeted skillset training programs were offered to various poverty-stricken residents.

\footnotetext{
Provincial employment poverty alleviation base refers to all kinds of employers identified by the Guangdong Provincial government to assume the social responsibility to promote employment, standardize employment in accordance with the law, actively develop employment to reach a certain number or proportion of registered poor labor force, and maintain their stable employment (employment for more than 6 consecutive months).
} 
Guangdong also provided funding support for occupational training programs. For example, the Cantonese Cuisine Chefs Program offered 12,000 training opportunities to poverty-stricken people, while the Guangdong Housekeeping Program offered 23,100 training opportunities. Nearly CNY56.5 million was spent in cultivating over 10,000 rural e-commerce talents. Teachers were sent to conduct the teaching programs in rural areas and promote the employment of rural talents. Students from poverty-stricken families were allowed to enroll with tuition fee exemption. Guangdong allocated CNY120 million to poverty-stricken students studying at various vocational schools as a form of living allowance from 2016 to 2020. In addition, poverty-stricken students were encouraged to launch their start-ups with funding support through various innovation and entrepreneurship competitions and employment incubation platforms. A case-by-case poverty alleviation reporting system was established to offer targeted poverty-alleviation follow-up services.

\section{Optimize the Leading Role of Government Procurement in Promoting "E-commerce + Consumption for Poverty Alleviation"}

The Department of Finance of Guangdong Province, the Guangdong Provincial Office of Poverty Alleviation, the Guangdong Provincial Supply and Marketing Cooperative, and other departments have strengthened cooperation, increasing their efforts and taking multiple measures to implement the requirements of the Notice of the Ministry of Finance, the State Council Poverty Alleviation Office, and the All-China Federation of Supply and Marketing Cooperatives on Issuing the Implementation Plan for Government Procurement of Agricultural and Sideline Products in Poor Areas. The "Guangdong Government Procurement Hall for Poverty Alleviation" (referred to as the "Hall for Poverty Alleviation") was launched online. As one of the special online halls for the Guangdong Provincial Government procurement, the Hall for Poverty Alleviation follows the principle of "government establishment, market operation, and cooperative operation among enterprises". It integrates online display, transaction, tracking of products and delivery, and other one-stop functions of agricultural and sideline products in poor villages in Guangdong, including those with partner enterprise assistance to pursue poverty alleviation in the eastern and western regions. These measures demonstrate government procurement for consumption to help overcome poverty nationwide. As of August 2020, the Hall for Poverty Alleviation had 318 merchants, with 566 types of agricultural and sideline products in 6 categories. A total of 352 orders had been made, with transactions amounting to CNY1.9 million.

Guangdong also funds exhibitions and live broadcasts, to help build a sales channel with online and offline integration. There are also special funds to help establish innovation and start-up platforms to attract new agricultural business entities. For instance, Heyuan City has invested CNY3.6 million in special funds to build the "Shenhe Poverty Alleviation Service Center". CNY462.5 million in central and provincial fiscal funds have been invested to support the implementation of e-commerce in rural areas and expand sales channels for agricultural products.

\section{Create New Ways to Use Poverty Alleviation Funds, and Explore Investment in Assets for Poverty Alleviation}

To explore new paths for the expansion of the collective economy in poor villages, photovoltaic projects were developed to provide new and stable source of extra income for farmers. Before the end of 2020, there were 2,252 photovoltaic projects with a total construction scale of about 620,000 kilowatts. They have been included in the national subsidy list and operate on a national scale, enabling 102,900 poor households to increase their income. 
To support the long-term investment in assets, a program called "share investment and guaranteed dividends" was developed, which promoted the asset ownership of the projects and the long-term development of poverty alleviation projects, such as hydropower construction, industrial parks, and agro-industries. The development model of "enterprises (cooperatives), agricultural bases and poor households" is promoted wherein poverty alleviation funds can be switched to equity funds, so that poor households (especially those without labor capacity) will have equity dividends, and new blood will be pumped into these villages.

\section{E. Support Targeted Poverty Alleviation Through the Tourism Industry}

To strengthen the tourism industry to support targeted poverty alleviation, Guangdong continues to finance and improve rural tourism infrastructure, and create a tourism brand of "Beautiful Villages in Guangdong". Financial support is offered for employment training in the tourism industry; training courses for rural tourism and poverty alleviation; and upgrading of the professional skills of entrepreneurs, village officials, and grassroots administrative staff. To support the protection and continuation of intangible cultural heritage resources in lagging areas, annual special subsidies of CNY30,000 at the national level and CNY20,000 at the provincial level are being extended to representatives of the intangible cultural heritage. ${ }^{8}$

\section{F. Implement Collaboration Between the Eastern and Western Regions}

Arrangements were underway for collaboration on poverty alleviation between the eastern and western regions to help poor residents in the central and western provinces find jobs and get out of poverty. Since 2016, Guangdong has continuously innovated mechanisms and improved policy support to deepen the integration of staggered industrial transfer and enhance the "blood-making" function. First, the Provincial Government of Guangdong has provided job information, technical training, unemployment job transfer, and other safeguard services. It has implemented policies such as tax reduction and/or exemption and financial subsidies, and offered detailed guidance on protecting the legal rights and interests of all parties in labor relations. As a result, 3.9 million poor people from central and western provinces have found employment in Guangdong. Second, Guangdong has helped the registered poverty-stricken people to find jobs locally. With this assistance, 249,300 people were employed in 2019. Third, Guangdong has guided 491 enterprises to invest and start businesses in areas where they cooperated in poverty alleviation. Those enterprises have made actual investments of CNY21.2 billion, helping 1.2 million people escape poverty. Social aid funds (including donations and materials) reached CNY3.1 billion.

8 The representative inheritor of the intangible cultural heritage refers to the inheritor who bears the inheritance responsibility of the representative projects of the intangible cultural heritage, is representative in a specific field, and has a great influence in a certain area, and is recognized by the government. 


\section{CHALLENGES AND PATHWAYS TO POVERTY REDUCTION}

Guangdong has continuously deepened its efforts in poverty reduction across different stages and has made significant achievements. It took the lead in exploring various ways to help people in relative poverty. However, it may not be smooth sailing in the battle against poverty. A comprehensive and high-quality plan is needed at this final stage.

There are three difficulties:

(i) It is difficult for poor households to increase their income steadily. The rural tourism industry has not yet fully recovered, and it is difficult to find a job and maintain employment. The channels through which the poor households can increase their income are limited.

(ii) It is difficult to consolidate achievements and prevent poverty. Poverty alleviation from industry and employment is not stable, particularly for the handicapped and unskilled groups. There are still many near-poverty households, households vulnerable to shocks, or other groups in need of help to prevent their falling into poverty.

(iii) It is difficult to remedy the shortcomings in rural infrastructure. The prevention and control of COVID-19 and extreme weather conditions have posed greater challenges to rural public services and utilities, and the task of remedying these shortcomings remains arduous.

There are three additional challenges:

(i) Motivation and long-term poverty alleviation. Poor households have not yet been motivated from inside out; the "wait-and-see" mentality is still ubiquitous. It is necessary to step up efforts in organizing, mobilizing, and guiding people. It takes time to strengthen governance that can successfully promote poverty alleviation. Particularly at the grassroots level, a new governance mechanism for poverty alleviation needs to be established.

(ii) Rural revitalization. Weak growth of the town economy is an obstacle to grassroots governance. The development of towns and villages is uneven: the phenomenon of weak towns and strong villages, or weak towns and villages, is common. Some public services and utilities are still inadequate.

(iii) Promoting convergence and forming synergy. To keep the vulnerable population out of absolute poverty, rural revitalization, which can provide stable and realistic labor income opportunities, is necessary.

In the overarching program for poverty reduction and alleviation in Guangdong during the Fourteenth Five-Year Plan, 2021-2025 period, securing fiscal allocation for continued poverty alleviation will be key. Guangdong will take more targeted approach in fiscal measures and capital investments to make sure that measures are tailored to local conditions and individual needs.

To promote better monitoring, Guangdong province plans to build the "Guangdong TCC6 Information Platform for Poverty Analysis, Early Warning, Prevention and Control" to help identify and monitor vulnerable people; improve the guarantee mechanism for people living in relative poverty; and create innovative methods of financing, management, distribution, and supervision.

The targeted investments aim to effectively contribute to rural revitalization while benefiting the vulnerable groups to provide the opportunities for labor income. The agriculture sector, where low income population is concentrated, needs to be developed further with effective use of agriculture-related funds. 


\section{APPENDIX 1: CASE STUDY ON POVERTY REDUCTION IN NANXIONG CITY IN SHAOGUAN}

\section{Basic Information}

Nanxiong City has a total of 208 administrative villages, with 68 selected for the targeted poverty alleviation campaign. In 2015, the city ranked fifth in Guangdong Province and first in Shaoguan ${ }^{9}$ in terms of number of poverty-stricken villages at the county level. There were 14,534 registered poverty-stricken individuals from 5,714 households, with the poverty prevalence rate at 4.6\%. In implementing Communist Party of China (CPC) General Secretary Xi Jinping's basic strategy of targeted poverty alleviation and reduction, the CPC Nanxiong Municipal Committee and Nanxiong Municipal Government played the lead role of "front-line command", placing poverty alleviation as the most important political task.

Between 2016 and 2019, the per capita disposable income of poor households had increased from CNY3,246 to CNY15,697; the average collective income of provincial-level poverty-stricken villages had increased from CNY23,700 to CNY156,000; and the per capita disposable income of villagers had increased from CNY6,637 to CNY15,695. In 2016, Nanxiong ranked first in Guangdong in a performance evaluation on poverty alleviation carried out by relevant provincial authorities. For three consecutive years, from 2017 to 2019, Nanxiong ranked first among all counties and districts in Shanguan in terms of poverty alleviation performance.

As of June 2020, all registered poverty-stricken people and provincial-level poverty-stricken villages had passed the poverty reduction standards, and in July 2020, Nanxiong was officially recognized by Guangdong Provincial Office of Poverty Alleviation as Guangdong's first model pilot county with a sound and long-term mechanism to tackle poverty.

\section{Successful Practices and Experience}

\section{Establish a "Three Priorities" Mechanism}

The poverty alleviation and reduction efforts of Nanxiong City were closely linked to CPC directions that created a "three priorities" mechanism, as follows: (i) the importance of optimizing grassroots organizations, (ii) decision making by CPC leaders, and (iii) exemplary role of the CPC. As a result, party organizations were able to play a leading role in poverty alleviation and reduction among all natural villages (villager groups), rural cooperatives, and other economic entities in rural areas. The officials offered targeted poverty alleviation services to rural villagers, and established new agricultural business entities and other new mechanisms that would serve as the driving forces behind poverty alleviation. As a result, the city's 1,085 grassroots organizations and 21,236 party members successfully mobilized poverty alleviation and reduction initiatives. In June 2018, the People's Government of Guangdong Province held an on-the-spot meeting in Nanxiong, called "Leveraging Party Building to Promote Poverty Alleviation and Reduction."

9 Shaoguan is a prefecture in the Northern Guangdong Province which includes Nanxiong City. 


\section{Be Detailed on the Poverty Alleviation Plan}

As a county carrying out a provincial-level initiative on poverty alleviation and reduction, Nanxiong formulated an Implementation Plan on Poverty Alleviation and Reduction, established a special taskforce, and took active measures to enhance the quality of poverty alleviation and reduction. First, the local government carried out a comprehensive survey on the poverty-stricken people, for example, who are affected by the COVID-19 pandemic. Nanxiong created a ledger for 473 people in extreme poverty from 160 households, and set up household-specific poverty alleviation policies. As a result, 77 households were able to eradicate poverty through employment assistance, 16 households through industry support, and 67 households through government subsidy. Rural villagers were encouraged by means of "extending awards other than subsidies" and "one-to-one employment support" to find jobs or carry out agricultural activities to enhance their self-sufficiency level.

Second, by following standards in terms of safety, aesthetics, functionality, and good hygiene, the Nanxiong local government carried out a campaign to improve the living conditions of 1,654 households. A drinking water improvement project was also launched, resulting in installing running water free of charge for 172 poverty-stricken households. Efforts in improving the rural environment was also successfully carried out.

Third, the local government stepped up efforts to help rural villagers cultivate a positive disposition when carrying out the poverty alleviation initiatives. A follow-up visit mechanism was established, where government officials would regularly visit poverty-stricken households and offer any needed assistance.

\section{Poverty Alleviation Through Industrial Development}

Nanxiong identified industrial development as the most important instrument in helping rural villagers get out of poverty. It introduced innovations in industrial development in terms of project establishment, investment, operation, sales, supervision, and actual implementation, to achieve the target of "stably helping poor rural residents lift worry on food and clothes, guarantee their basic medical care and housing safety, and improve the main indicators of basic public services equal to the average level around Guangdong Province". Nanxiong established Guangdong's first county-level poverty alleviation investment company, building eight agricultural bases, each with a size over 1,000 mu (about 66.67 hectares), which were planted with plantation crops such as navel orange, crayfish, tea, herbal medicine, passion fruit, and sunshine rose grape.

To actively involve villagers in poverty alleviation, many innovative projects were introduced in terms of land use, capital, and labor. Six-mechanism schemes such as "rent + salary + equity capital" and "cooperatives + agricultural bases + poverty-stricken households" resulted in poor villagers realizing a per capita annual income increase of CNY3,500. In December 2019, Nanxiong's experience on poverty alleviation through industrial development and the 6-mechanism innovations were acclaimed by the official WeChat account of the State Council Poverty Alleviation Office.

\section{Strengthen Asset Management and Integrate with Rural Revitalization}

When Nanxiong was selected to carry out provincial-level reform for long-term poverty alleviation, the Nanxiong government seized the opportunity and further strengthened its poverty alleviation asset management, while deepening reforms on its property rights system. As a result, over 1,469 projects in the areas of poverty-relief industries, rural infrastructure, and public service were established, generating poverty-relief assets of CNY498.5 million, of which CNY297.6 million were operating poverty-relief assets. CNY52.2 million of cumulative poverty-relief assets were generated, providing much needed financial security for dividend distribution among poor households, public welfare projects in poor villages, and further investment to finance the poverty-relief industry. 
The Nanxiong government regulated poverty alleviation assets in terms of rights verification (ownership, management, and income rights), administration, distribution, and supervision. It formulated two management modes, namely, "investment company + poverty alleviation asset management" and "party building at grassroots level + investment platform + poverty alleviation asset management". Nanxiong also refined and issued the distribution plan for revenues generated from poverty alleviation efforts, covering public welfare job empowerment, merit-based point system, and evaluation prior to dividend distribution, to ensure that sufficient funding support will be made available when carrying out both the poverty alleviation initiative and rural vitalization initiative.

\section{Introduce Special Mechanisms to Ensure the Sustainability of Poverty Alleviation Efforts}

Shaking off poverty is not the end of the pursuit, instead, it is the beginning of a new journey to a bright future. In carrying out the pilot reforms, Nanxiong adhered to guidelines laid out by the CPC Guangdong Provincial Committee and Guangdong Provincial Government. It considered local conditions, paying extra attention to disadvantaged groups, especially those who suddenly became poor as a result of unexpected events. Other vulnerable groups suffering from major diseases and chronic diseases, together with left-behind children, were considered to establish eight working mechanisms, including the Early Warning Response Mechanism for the Poverty-stricken Rural Resident in Nanxiong City and Implementation Opinions on Further Strengthening Poverty-relief Asset Management (trial).

So far, 326 rural residents from 105 households have been identified and included in the special assistance scheme. A poverty alleviation effectiveness contest was carried out in all 208 rural villages. Fifty people with serious and chronic diseases, 678 women with intellectual disabilities and child patients, 106 left-behind children from families with limited or no guardianship capacity, and 1 family with "zero employment" status (efforts had been made to allocate public welfare jobs for its family members), have all been identified and corresponding poverty alleviation programs were in place for these disadvantaged groups. 


\section{APPENDIX 2: CASE STUDY ON POVERTY REDUCTION IN LIANZHANG VILLAGE, YINGDE, QINGYUAN}

\section{Basic Information}

Located in Lianjiangkou Town, Yingde, Qingyuan, Lianzhang Village covers a total area of 31.8 square kilometers. Its main industries include rice, vegetables, Shatangju (tangerines), peanuts, and tea cultivation. In 2015, Lianjiangkou Town governed 9 villagers' committees and 233 villager groups, while Lianzhang Village governed 17 villager groups comprising 482 households and 2,225 villagers. The annual per capita disposable income in the whole village in 2015 was CNY7,720. The collective economy of Lianzhang Village started off as very weak, and the village was listed as a provincial poverty-stricken village in 2016. Its path to poverty alleviation was a showcase for the 2,277 poverty-stricken villages in Guangdong Province.

Under the leadership of its Poverty Alleviation Team, Lianzhang Village has achieved notable results in poverty alleviation. By 2016, households enjoying the five guarantees and households enjoying the minimum living guarantee due to incapability to work in the village had all their basic needs met and were lifted out of poverty. In 2017, 25 poverty-stricken households (80 people) with working capacity in the village achieved the pre-poverty alleviation objective, meeting eight criteria, and the average per capita disposable income in the entire village had reached CNY9,256. In 2018, all poverty-stricken households in Lianzhang Village reached the pre-poverty alleviation objective. At the end of 2019, the per capita disposable income of the poverty-stricken households reached CNY19,188, far exceeding the poverty line, and completing Lianzhang Village's achievement of the poverty alleviation objective.

\section{Successful Practices and Experience}

\section{Strengthen Organization and Leadership}

The village-based Poverty Alleviation Team was committed to helping Lianzhang Village eradicate poverty. Since it was stationed in the village in 2016, the team kept in mind the mission to lead the villagers out of poverty. Officials stationed in the village actively participated in training and learning, and coordinated all aspects of poverty alleviation projects ranging from the paving of village roads, checking on the village property, and ledger keeping.

The village-level Communist Party of China (CPC) organization was the overall coordinator of all poverty alleviation projects. In order to improve the previously weak and fragmented village party committee, the party organization was strengthened, paying attention to the development of party members, regulating party branch development, and promoting the party members' ability to lead development and serve the people.

Poverty alleviation begins with aspirations. At the village level, education was promoted, and activities were carried out frequently for people to "feel grateful" and "advance bravely." At the same time, a Council of the Party and the Masses was established, and the Lianzhang Rural Revitalization College was built, to create an environment of competitiveness and help villagers gain confidence and the will to overcome difficulties and adversities. 


\section{Improve Public Services and "Build a Beautiful Village"}

Transportation, power grid, communication, and other infrastructure have improved greatly, which helped Lianzhang Village become prosperous. Road construction was the first priority for poverty alleviation. With the joint efforts of the general party branch, party members, and villagers of Lianzhang Village, the sand-clay road with a total length of 4.5 kilometers in Dongkeng, Qikeng, Aobei and seven other village roads were paved by the end of 2017. The muddy road in the village has been turned into an even, concrete road. With the help of Country Garden Group, Lianzhang Village continued to pave the 1.5-kilometer-long road in the village at the beginning of 2019, and realized the objective of "connecting every village with roads" in the whole central village.

Facing issues such as frequent power outages and power failures, the Poverty Alleviation Team and the village's CPC branch attached great importance to power grid transformation, paid close attention to the safe use of electricity around Lianzhang Village, designated a party member service team to walk around Lianzhang Village, and to plan for the electric wire layout for the safe use of electricity, so as to eliminate potential safety hazards. Since 2015, the power grid structure in Lianzhang Village has been further improved. Multiple guarantee measures have been adopted to achieve zero blackouts. More than 200 villagers have equipped their houses with smart green electricity. The former poverty-stricken village has stepped into a new era of smart green grids.

Poverty alleviation in an industrial area urgently needs internet support. In 2019, China Telecom (Qingyuan Branch) began to build $5 \mathrm{G}$ base stations in Lianzhang Village through its Optical Fiber Network Construction Project. China Telecom had to overcome many difficulties such as inconvenient transportation and equipment transfer and shortage of communication infrastructure in mountainous areas. It provided Lianzhang Village with a high-quality communication network, to make Lianzhang Village a comprehensive demonstration benchmark for rural revitalization in Qingyuan City and even in the country.

\section{Comprehensively Promote the Project "Three Cleansing, Three Demolition, and Three Rectification"}

Since 2016, Lianzhang Village has actively responded to provincial and municipal calls for agricultural funds to be integrated and used to expand investment. With the help of Country Garden Group, Lianzhang promoted the project "Three Cleansing, Three Demolition, and Three Rectification", which aims to improve and share its experience on comprehensive living environment improvement for Qingyuan and even the eastern, western, and northern regions of Guangdong Province.

At the end of 2017, with the complete renovation of dilapidated houses and paving of village roads, Lianzhang Village had accomplished comprehensive rural environmental improvements. It paid close attention to projects such as clean rural environment, separation of people and livestock in the rural areas, infrastructure construction, public service facilities, garbage and sewage treatment, and ecological environment improvement, completely solving the issues of polluted environment, poor facilities, and lack of planning in rural areas. The following were the main projects:

(i) Project on "Small Toilets for Great People's Livelihood." The village accelerated the "toilet revolution" and built the first star-rated public toilet at the entrance of the central village, setting a good example for other villages.

(ii) Centralized water supply, and rain and sewage diversion project. The village was able to supply 1,500 cubic meters per day, fully satisfying the needs of the villagers for production and living, and solving the water problem in the Rural Revitalization College and the Modern Agricultural Science and Technology Demonstration Park. 
(iii) "Beautiful village" development project. The village promoted waste segregation in an orderly manner, creating standards that were in line with urban standards, and making garbage segregation a new fashion and trend in Lianzhang Village. Today, Lianzhang Village has become one of the Top Ten Most Beautiful Villages in Yingde, and the "beautiful village" development project has achieved remarkable results.

\section{Promote Development of Convenient and Friendly Livelihood Services}

In addition to the improvement of hardware facilities, perfection of "soft" facilities such as transportation, finance, and other livelihood services also provided strong support for rural revitalization. At the end of September 2019, Lianzhang Village officially launched a passenger transport line from Yingde Bus Station to Lianzhang Village, providing local people with safe, comfortable, and convenient travel services.

To meet the needs of education and ensure the kids' safety on the road to school, Lianzhang Village promoted the project Escort Rural Children to School Safely and established a standardized and orderly school shuttle bus operation mode and management mechanism with specific functions.

Meanwhile, the Party-mass Service Center was established to act as a "one-stop settlement center to assist villagers in their various needs." With the help of the Poverty Alleviation Team, Lianzhang Village raised CNY550,000 to build this new public service station located in the center of Lianzhang Village. It is equipped with party member activity rooms, meeting rooms, family planning service rooms, etc. The center provides great convenience for villagers and assists in people's livelihood problems. Cadres work in centralized sites at fixed office hours and have helped realize the objective of "village affairs being solved in the village".

The village also introduced an integrated e-government service machine to provide convenient access to various government services. Yingde Rural Commercial Bank took the lead in promoting its self-service to the village, breaking the original deadlock of zero bank outlets. The bank built the first service point in the village, equipped it with a cash receiving system (CRS) or automated teller machine, and set up credit services, promoting the adoption of financial services by the villagers.

\section{Strengthen Guidance via Planning and Promote Project Implementation}

Governments at the municipal, town, and village level have always attached great importance to poverty alleviation through the development of industries. They have issued a number of development plans and implemented them, and promoted poverty alleviation projects by developing agricultural industries. The Qingyuan Municipal Bureau of Agriculture and Rural Affairs, together with the Guangdong Academy of Agricultural Sciences, carried out field investigation and research in Lianzhang Village and its surrounding villages in accordance with the requirements of the policy thrust of Poverty Alleviation to Villages, Planning for Households, Integration of Resources, and Joint Efforts to Tackle Tough Problems, to determine the causes and problems of Lianzhang Village's poverty. All these helped determine the progress of the agricultural industry, which enabled the drawing up of a long-term industrial development plan for uplifting the poor village with technological and industrial assistance. With the implementation of the Work Plan for Construction of Lianzhang Village Demonstration Site in Lianjiangkou Town, the implementation of the Lianzhang Village Plan has proceeded briskly.

\section{Promote Village Development and Poverty Alleviation Via Increased Employment in Industries}

Lianzhang Village has committed to building a long-term poverty alleviation mechanism by introducing processing industries and agricultural enterprises, developing service industries, adjusting the industrial structure, and fostering local market operators. These would allow the introduction of industrial 
projects, and build a system linking industrial projects with households needing assistance. Lianzhang Village has also dedicated itself to incorporating registered, relatively poor households into the industrial development chain, mobilizing their enthusiasm for production, and stimulating their desire and motivation to get rid of poverty and prosper.

In Yingde, the local government adopted the poverty alleviation action, "Hundreds of Enterprises to Help Hundreds of Villages", and explored a poverty alleviation model of "agriculture + industry". This involved, first, pairing agro-industry potentials with enterprises, which in turn organized various activities such as helping establish vegetable, sericulture, fruit, tea, and other agricultural associations. By developing agricultural industries, selecting the right projects, and cultivating "blood-forming" industries, poverty alleviation was pursued.

After this pairing, selecting the right industries that could help poverty alleviation was the second stage. The village determined the industry assistance plan based on the market, wherein the paired company would provide technical support for industrial projects in the corresponding village on a regular basis, strengthen the skills of project staff through training, improve the quality of project products, create high-quality brands, and build a good reputation by word of mouth.

Third, training leaders led others to prosperity. Private enterprises extended advice and assistance to rural leaders who could lead others to prosperity in the paired villages, and supported returning migrant workers to start their own businesses.

Guided by industrial development, Lianzhang Village proactively helped villagers find employment in the local area. Through poverty alleviation workshops, Country Garden's Modern Agricultural Science and Technology Park, and agritainment projects, priority was given to hiring local villagers, especially locals with working capability from registered poor households. This earned double benefits for villagers in terms of land transfer costs and labor costs, thus shifting their roles to agri-industrial workers. At the same time, the village helped capable individuals shift their roles from agri-industrial workers to small business owners, realizing the objective of self-employment.

\section{Promote the Integration of Three Sectors and Enhance Industrial Value}

Lianzhang Village is developing ecotourism to make use of agriculture and the natural landscape to create a series of leisure agricultural tourism routes; create new places for leisure tourism, agricultural experience, food tasting and shopping, and entertainment and vacation; and to exploit the natural agricultural landscape and value of agricultural tourism resources. Pursuing the idea of "strengthening primary industry, aligning with the secondary industry, and connecting the tertiary industry," Lianzhang started with several perspectives such as rural tourism, commerce and trade, and asset returns to promote integrated development of the three sectors and change from "blood transfusion" to "blood-forming" pursuits.

Rural ecotourism could retain locals and also bring back some entrepreneurial talents from other places to promote agricultural development. In partnership with enterprises, Lianzhang Village built the Xiancao Park, a place for agricultural sightseeing, a fruit-picking garden, and ecological tea garden, thus promoting the development and enhancing the value of ecological agriculture and leisure agriculture. In accordance with the development philosophy of "holistic scenic area", the village integrated poverty alleviation with industry development by constructing a beautiful village, promoting rural tourism, modern farms, and the like. Through the development of cultural tourism, agricultural science popularization, country bed and breakfast establishments, and similar tourism initiatives, Lianzhang Village strengthened the new tourism business type and business model, and promoted the interconnected development of the three economic sectors. 


\section{Support Industrial Upgrading with Agricultural Science and Technology}

Development of agricultural science and technology would help promote rural industrial upgrading, improve efficiency of industrial management, and facilitate poverty alleviation through industrial development. To eliminate poverty and achieve long-term development in Lianzhang Village based on its resources and industrial foundation, the village paid close attention to leading industries such as ecological tea, vegetables (including bamboo shoots and edible fungi), and special fruits. It has carried out agricultural development projects following the philosophy of "Formulating an Industry Plan, Proposing a Set of Technology Regulations, Fostering a Batch of New Farmers, Providing a Batch of Seeds and Seedlings, Cultivating a Batch of Business Entities, Forming Multiple Industrial Chains and Building a Batch of Family Farms."

Tapping the scientific and technological innovation advantages of scientific research institutes, agricultural universities, and enterprises, Lianzhang Village built a distinctive full-chain ecosystem that combines expert teams, industrial clusters, agricultural science platforms, and industrial services, to inject technological impetus to Lianzhang Village's long-term sustainable development.

Lianzhang Village is one of the very first villages in the PRC to be equipped with a $5 G$ network. With the distinctive features of wide bandwidth, high speed, and low latency, 5G could play a huge role in the development of smart agriculture, rural e-commerce, and green agricultural production, helping win the antipoverty battle.

\section{Provide Comprehensive Support with Diverse Elements}

Talent is the number one productive force. With the support of party committees and government departments at all levels, Lianzhang Village has implemented talent development measures such as "Precisely Dispatch Officials to Poverty Alleviation Projects, Improve Measures to Recruit Talents, Rely on Platforms to Train Talents, and Develop Nostalgic Culture to Gather Talents". In this way, Lianzhang Village has formed a poverty alleviation team that relies on the poverty alleviation officials who interact with the external scientific and technological experts, and who work with local talents. This provides strong talent support to achieve the targeted poverty alleviation goal as scheduled, and secure a long-term poverty alleviation mechanism in Lianzhang Village.

Lianzhang Village's Poverty Alleviation Team has basically eliminated system barriers that prevent talents from working and living in the village. With the help of Yingde's talent introduction and rewards system, Lianzhang Village established the employment and entrepreneurship information registration, and aligned it with the unified provincial public employment and entrepreneurship service information system. The village has formulated policies that encourage graduates, migrant workers, and farmers to return home to start a business. It has proactively encouraged and guided veterans, migrant entrepreneurs, and local talents to return to their hometowns; participated in the development of committees; and promoted the development of the village-level collective economy concept. This is a virtuous circle of self-prosperity while promoting common prosperity; and common prosperity facilitating self-prosperity.

The village has made full use of platforms such as the Rural Revitalization College Modern Agricultural Technology Demonstration Park, and Cantonese Cuisine Master Project, to vigorously cultivate new vocational, agricultural, rural, and practical talents. It has conscientiously selected outstanding college graduates to work in Lianzhang Village; recruited graduates to fill community-level posts in education, agriculture, health care, and poverty relief; and trained a batch of rural craftsmen and cultural talents. In 2019, Lianzhang Village established the Talented Townsmen Association to highlight the advantages of rural talents who are more familiar with the local people, places, and affairs; and to encourage talents to come back to work in village governance. 
Land, capital, and other elements are also important guarantees for increasing income and reducing poverty in Lianzhang Village. With the reform and improvement of the rural endowment insurance system and the new cooperative medical care system, land could be considered as the modern social security system for farmers. The agricultural production function of land in Lianzhang has been restored. Lianzhang Village is committed to the consolidation of rural land resources, integrating land through various methods such as land exchange and merger, contiguous contracting, collective management, and circulation. Scale land management could promote development of agricultural industries and enhance local employment, while pooling lands and drawing dividends on these land shares could further increase the income of rural residents, reduce poverty in rural areas, and break the urban-rural dual social structure system.

The village has strengthened services support to agriculture and has integrated all types of agricultural production service entities and resources at the primary level; built an agricultural production service platform; and provided farmers with production technology, agricultural material supply, agricultural product sales, agricultural machinery, rural finance, and other five-in-one production services.

Indeed, by investing in poverty alleviation projects and deriving income from land, mountains, forests, and other resources, the village has shifted natural resources to funds, funds to equity, and farmers to employees. 


\section{REFERENCES}

Asian Development Bank. 2021a. https://www.adb.org/projects/46079-002/main.

_. 2021b. https://www.adb.org/projects/39653-023/main.

Communist Party of China Guangdong Provincial Committee and the People's Government of Guangdong Province. 1984. "Developing Mountain Areas and Achieving Prosperity by Mountain Agriculture."

- 2009. "Opinion on the implementation of Plan the Poverty Alleviation to Households, Allocate Responsibilities to Specific Persons."

Guangdong Provincial Bureau of Statistics. 2020. Guangdong Statistical Yearbook 2020. Guangdong: China Statistics Press.

Guangdong Provincial Department of Finance.

Guangdong Provincial Poverty Alleviation and Development Office. 


\section{Approaches to Eradicate Absolute Poverty in Guangdong Province, the People's Republic of China}

This case study focuses on measures adopted by Guangdong Province to enhance the efficacy and efficiency of spending programs for poverty alleviation until the end of 2020, when the province achieved the eradication of absolute poverty. First, a diversified approach to poverty alleviation was followed. Second, financing was allocated for industrial development projects. Third, poverty reduction measures included training for self-development. Fourth, targeted poverty reduction was linked with rural revitalization. Last, poverty reduction funds were closely supervised to ensure transparency. The challenge remains on how the gains from absolute poverty eradication and rural revitalization will address relative poverty.

\section{About the Asian Development Bank}

ADB is committed to achieving a prosperous, inclusive, resilient, and sustainable Asia and the Pacific, while sustaining its efforts to eradicate extreme poverty. Established in 1966, it is owned by 68 members -49 from the region. Its main instruments for helping its developing member countries are policy dialogue, loans, equity investments, guarantees, grants, and technical assistance. 